\title{
Effect of the hydrogel incorporation on different substrates on the rooting and quality of clonal Eucalyptus seedlings
}

\author{
Efeito da incorporação de hidrogel em diferentes substratos na \\ rizogênese e qualidade de mudas clonais de eucalipto
}

\section{Yolanda Xavier da Cruz Neres ${ }^{1}$, Glauce Taís de Oliveira Sousa Azevedo ${ }^{2 *}$, Anderson Marcos de Souza', Gileno Brito de Azevedo ${ }^{2}$ and Paulo Eduardo Teodoro ${ }^{2}$}

\begin{abstract}
Resumo:
A propagação vegetativa exige maior controle sobre o substrato, tendo reflexo qualitativo e quantitativo dentro de toda cadeia produtiva de mudas até o plantio. Este trabalho teve como objetivo avaliar a rizogênese e qualidade de mudas clonais de eucalipto produzidas em três diferentes substratos comerciais com e sem incorporação do hidrogel. A pesquisa foi realizada no viveiro da empresa R\&S Florestal, Planaltina, Distrito Federal. Para a produção das mudas foram utilizados os substratos comerciais: Vivatto Slim Plus ${ }^{\circledR}$, Bioplant ${ }^{\circledR}$ e Tropstrato Florestal ${ }^{\circledR}$, com e sem hidrogel $\left(2 \mathrm{~g} \mathrm{~L}^{-1}\right)$ da marca Forth $\mathrm{Gel}^{\circledR}$, e o material genético (miniestacas) utilizado foi o clone VM01. Foi utilizado o delineamento inteiramente casualizado (DIC), com seis tratamentos em esquema fatorial $3 \times 2$ (três tipos de substrato $x$ presença e ausência de hidrogel), com quatro repetições. Aos 35 dias após a emergência (DAE) avaliou-se a rizogênese das miniestacas e aos 101 DAE foi avaliado o desenvolvimento das mudas. A eficiência do hidrogel para a melhoria da qualidade da rizogênese das miniestacas e desenvolvimento das mudas depende das características físicas e químicas dos substratos.
\end{abstract}

Palavras-chave: minisestaquia, hidrogel, análise de substratos.

\begin{abstract}
:
Vegetative propagation requires greater control over the substrate, having a qualitative and quantitative reflection within the entire seedlings production chain until the planting. This work aimed to evaluate the rooting and quality of clonal eucalyptus seedlings grown on three different commercial substrates with and without hydrogel incorporation. The research was carried out at the nursery of the R\&S Florestal company, Planaltina, Federal District. For producing the seedlings, the following commercial substrates were used: Vivatto Slim Plus ${ }^{\circledR}$, Bioplant ${ }^{\circledR}$ and Tropstrato Florestal ${ }^{\circledR}$, with and without hydrogel $\left(2 \mathrm{~g} \mathrm{~L}^{-1}\right)$, Forth Gel ${ }^{\circledR}$, and the genetic material (mini-cuttings) used was the clone VM01. A completely randomized design was used, with six treatments in a $3 \times 2$ factorial scheme (three types of substrate $x$ presence and absence of hydrogel), with four replications. At 35 days after cutting, the rooting of the mini-cuttings was evaluated, and the seedlings development was evaluated at $101 \mathrm{DAE}$. The hydrogel efficiency for improving the rooting quality of mini-cuttings and seedlings development depends on the physical and chemical properties of the substrates.
\end{abstract}

Keywords: mini-cutting, hydrogel, substrate analysis.

\section{INTRODUCTION}

The increasing productivity and quality of the Eucalyptus forests in Brazil are due to their adaptability to the varied edaphoclimatic conditions, research on genetic breeding, advances in technologies and knowledge related to the vegetative propagation of this genus (FERRARI, GROSSI, WENDLING, 2004; SANTANA et al., 2013), for commercial production of plantlets with high genetic quality and plant health (PIMENTEL et al., 2016). The mini-cutting is a plant propagation technique most commonly used for producing eucalyptus seedlings (BENIN et al., 2013; BRONDANI et al., 2014; WENDLING,

1. Forestry Department, Universidade de Brasília - UnB. Brasília / DF, Brazil.

2. Forestry Department, Universidade Federal do Mato Grosso do Sul - UFMS. Chapadão do Sul / MS, Brazil. *Corresponding Author: glauce.azevedo@ufms.br 
DUTRA, 2010). This technique is a result of the improvement of cutting technique and aims to overcome the low rooting success by some clones in the nursery (MELO et al., 2011).

Although mini-cutting has provided improvements for seedling production, such as increased rooting percentages, improvement of the root system and decreased time for seedling formation (ALFENAS et al., 2004; TITON et al., 2003), many factors may interfere with the development and quality of seedlings. Among these factors, can be highlighted the genetic material, water and nutrient management systems, packaging, and substrates (PIMENTEL el al., 2016; SIMÕES; SILVA; SILVA, 2012).

Plant propagation requires greater control over the substrate, which in a simple way is the support for establishing propagules and has a qualitative and quantitative reflection within the entire productive chain until the planting. The substrate directly affects rooting, since it has the role of sustaining and allowing the good supply of oxygen and water to the base of the cutting and root development (HARTMANN et al., 2011). Thus, there may be a need for adaptation of a substrate by incorporating materials with desirable chemical, physical, biological and economic characteristics (DANNER et al., 2007).

The production of nursery seedlings requires the incorporation of specific technologies at each stage of the process (MALDONADO-BENITEZ et al., 2011), aiming at ensuring a superior quality in the seedlings. Hence, by incorporating products to the substrate that provide improvements on its physical and chemical properties can help to increase the quality of the seedlings. One of the products that have been used for this purpose is the hydrogel. This product provides an improved water retention to the substrate, making it gradually available to the roots (VICENTE et al., 2015). It is a conditioner able to improve the chemical and physical substrate properties (NAVROSKI et al., 2016a), and its incorporation into the substrate have been used for producing forest seedlings (AZEVEDO et al., 2015; BERNARDI et al., 2012; LIU et al., 2013; MALDONADO-BENITEZ et al., 2011; MEWS, 2014; NAVROSKI et al., 2016b,c, 2015; SOUSA et al., 2013). The use of hydrogel incorporated to the substrate is a promising alternative for improving the rooting of eucalyptus mini-cuttings, mainly in low-rooting materials (AZEVEDO et al., 2015).

Given the above, this study aimed to evaluate the rooting and quality of clonal eucalyptus seedlings grown on three different commercial substrates with and without hydrogel incorporation.

\section{MATERIAL AND METHODS}

\section{Study area}

The study was carried out at the nursery of the R\&S Florestal company, located in the rural area of the municipality of Planaltina, Federal District, close to DF-250, km 21, with coordinates $15^{\circ} 43^{\prime} 18,7^{\prime \prime} \mathrm{S}$ and $47^{\circ} 35^{\prime} 55,8^{\prime \prime} \mathrm{W}$. The region climate is predominantly Aw (Köpen), with two well-defined seasons, dry winter (July and August) and rainy summer (November and January), with annual rainfall above $1,500 \mathrm{~mm}$ and temperatures between $13^{\circ} \mathrm{C}$ and $28^{\circ} \mathrm{C}$ (SANTOS et al., 2014). The experiment was conducted from September to December 2015.

\section{Seedling production system}

For the production of the seedlings, different commercial substrates were used: Vivatto Slim Plus ${ }^{\circledR}$, Bioplant $^{\circledR}$ and Tropstrato Florestal ${ }^{\circledR}$. For each substrate, seedlings were produced with and without hydrogel incorporation. The hydrogel used was the Forth $\mathrm{Gel}^{\circledR}$, at a rate of $2 \mathrm{~g} \mathrm{~L}^{-1}$ of the substrate (AZEVEDO et al., 2015), incorporated in its dehydrated form. The basis fertilization used was the same used in the nursery seedlings production system (29.16 g of Basacote ${ }^{\circledR}$ and $12.15 \mathrm{~g}$ of Yorin master ${ }^{\circledR}$, for every $14 \mathrm{~L}$ of the substrate). All these products were incorporated into the substrate with the aid of a concrete mixer. The seedlings were grown in tubes $\left(55 \mathrm{~cm}^{3}\right)$.

The genetic material used was the clone VM01 (Eucalyptus camaldulensis Dehnh. $\mathrm{x}$ Eucalyptus urophylla S. T. Blake, MAPA registration $\left.n^{\circ} 20766\right)$. This clone presents low rooting percentage $(<50 \%)$, it is commonly sought for its excellent adaptability to the Cerrado biome, and its production is destined for charcoal and firewood.

The mini-cuttings were obtained at clonal mini-garden semi-hydroponic type. The mini-cuttings were obtained by shoots from 4 to $7 \mathrm{~cm}$ in length and at least two pairs of fully expanded leaves that were cut in their half-length to prevent water loss. During the collection, the mini-cuttings were conditioned in polystyrene boxes with water to avoid turgidity loss. Subsequently, they were staked on the substrate and placed for rooting at greenhouse with an average temperature of $37^{\circ} \mathrm{C}$ 
Neres et al. - Effect of the hydrogel incorporation on different substrates on

the rooting and quality of clonal Eucalyptus seedlings

and relative air humidity above $80 \%$, where they remained for 35 days. After this period, part of the mini-cuttings was used for rooting evaluation, and the other part was sent to the shaded greenhouse (50\% shading), remaining for 7 days. They were then transferred to suspended screen benches in full sunlight, remaining in these conditions until they completed 101 days after cutting (DAC), when the final evaluation of the experiment was carried out.

\section{Evaluation of rooting and development of the seedlings}

At 35 DAC, the rooting of mini-cuttings was evaluated through the following traits: percentages of survival (SM), rooting (RM) and callus formation (C); number of roots (NR); root system length (RSL) and mean root length (MRL), in centimeters; and root system dry mass (RSDM), in grams.

These traits were obtained after washing the root system to remove the substrate. Survival was assessed by direct counting of live mini-cuttings, which presented turgidity and no rotting at the base. Rooting was counted in mini-cuttings with root emission from the base larger than one centimeter (Figure 1A), while the presence of callus was counted in the mini-cuttings with tissue differentiation, however without root emission (Figure 1B). The number of roots was obtained by counting the roots emitted directly from the base of the mini-cutting. The root system length was measured with a millimeter ruler, from the insertion point of the roots in the mini-cutting to the largest end. The mean root length was obtained by measuring the length of each root larger than $1 \mathrm{~cm}$ and divided by the number of roots emitted. The dry mass of the root system was determined by using an electronic scale with an accuracy of $0.001 \mathrm{~g}$, after drying the material in an oven at $70^{\circ} \mathrm{C}$, until obtaining the constant dry mass.

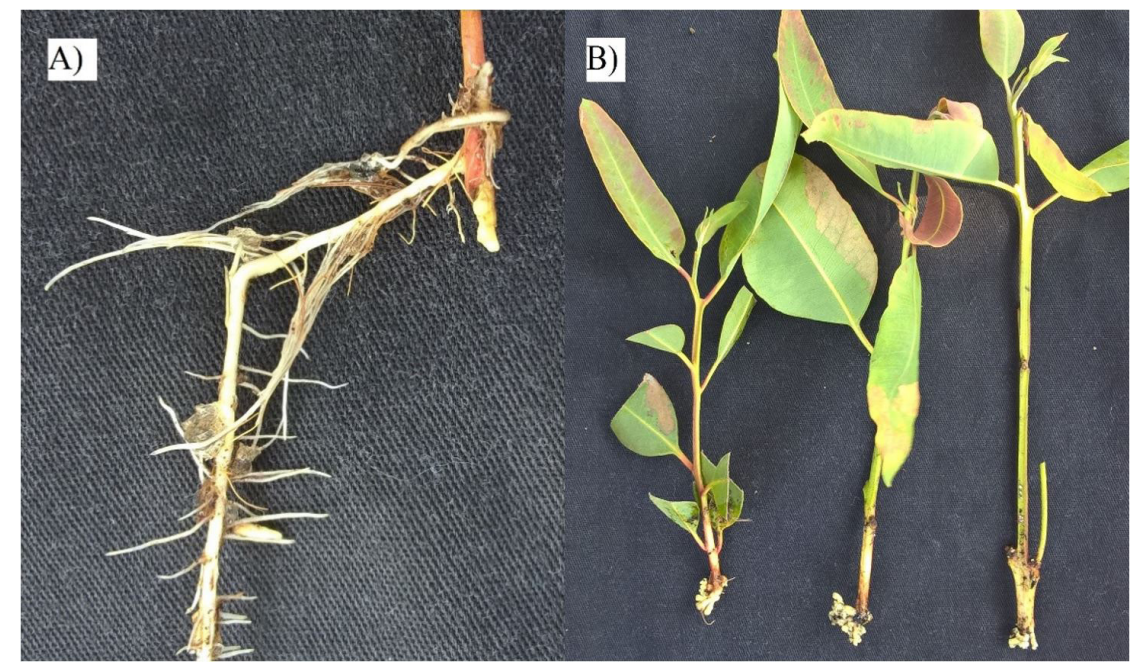

Figure 1. Mini-cutting with a root larger than one centimeter, emitted from the base $(A)$, mini-cutting with callus formation and without roots (B).

At 101 DAC the development of the seedlings was evaluated through the following traits: neck diameter (ND), in millimeters; shoot height (H), in centimeters; number of leaves (NL), shoot dry mass (SDM), root dry mass (RDM) and total dry mass (TDM), in grams, and relationships among traits such as height and diameter (HD) and Dickson quality index (IQD=TDM/(H/D+SDM/RDM).

The neck diameter was obtained with a digital caliper with an accuracy of $0.01 \mathrm{~mm}$, at the height of the substrate. Shoot height was obtained by measuring with a millimeter ruler, from the base of the seedling to the apical bud. The dry mass values were determined after the washing of the root system to remove the substrate. The seedlings were sectioned at the neck height to separate the root system from the shoot, with subsequent drying of the material in an oven at $70^{\circ} \mathrm{C}$, until obtaining the constant dry mass, and weighing the material on an analytical scale with an accuracy of $0.001 \mathrm{~g}$ (BÖHM, 1979).

\section{Substrate analysis}

The different substrates were evaluated for their chemical and physical properties. The chemical properties determined were: electrical conductivity (EC), using the conductivity meter, and hydrogen potential $(\mathrm{pH})$, with the potentiometer ( $\mathrm{pH}$ meter). For both analysis the dilution used was 1:5 (v/v), 
with deionized water. Physical properties evaluated were: wet density (WD), in $\mathrm{Kg} \mathrm{m}^{-3}$; dry density (DD), in $\mathrm{Kg} \mathrm{m}^{-3}$; and current humidity $(\mathrm{CH})$, in\%. With the aeration and water data available, total porosity (TP), aeration space (AS), readily available water (RAW), buffering water (BW), available water (AW), remaining water (RW), and water retention capacity under suction of 10, 50 and $100 \mathrm{~cm}$ of water column determined in base (WRC10, WRT50, WRT100).

Analysis was carried out at the Laboratory of Substrates of the Department of Vegetables and Forestry of the Federal University of Rio Grande do Sul, according to normative instructions $\mathrm{n}^{\circ} 17$ of the Ministry of Agriculture, Livestock and Supply (MAPA, 2007) and Fermino and Kanpf (2012). The results are shown in Table 1.

Table 1. Physical and chemical properties of the substrates used in the production of clonal eucalyptus seedlings.

\begin{tabular}{ccrrrrrr}
\hline Sample & & Trop $\mathbf{n h}$ & \multicolumn{1}{c}{ Trop $\mathbf{h}$} & \multicolumn{1}{c}{ Bio $\mathbf{n h}$} & \multicolumn{1}{c}{ Bio $\mathbf{h}$} & \multicolumn{1}{c}{ Viv $\mathbf{n h}$} & \multicolumn{1}{c}{ Viv $\mathbf{h}$} \\
\hline pH & $\mathrm{H}_{2} \mathrm{O}$ & 5.23 & 5.19 & 5.36 & 5.75 & 4.86 & 4.85 \\
EC & $\mathrm{mS} \mathrm{cm}^{-1}$ & 1.18 & 1.58 & 0.62 & 0.51 & 1.76 & 2.39 \\
WD & $\mathrm{Kg} \mathrm{m}^{-3}$ & 342.43 & 350.19 & 168.71 & 130.33 & 386.18 & 403.37 \\
DD & $\mathrm{Kg} \mathrm{m}^{-3}$ & 325.76 & 332.33 & 159.60 & 121.58 & 360.77 & 381.55 \\
CH & $\%$ & 4.89 & 5.10 & 5.40 & 6.78 & 6.59 & 5.41 \\
TP & $\%$ & 71.69 & 70.64 & 81.97 & 69.06 & 74.58 & 72.55 \\
AS & $\%$ & 21.71 & 21.62 & 52.92 & 43.63 & 9.40 & 5.80 \\
RAW & $\%$ & 15.91 & 13.15 & 5.48 & 0.77 & 20.68 & 23.91 \\
BW & $\%$ & 1.71 & 0.10 & 0.32 & 0.09 & 10.81 & 9.91 \\
RW & $\%$ & 32.36 & 35.77 & 23.25 & 24.58 & 33.69 & 32.93 \\
WRC10 & $\%$ & 49.98 & 49.02 & 29.05 & 25.44 & 65.18 & 66.74 \\
WRC50 & $\%$ & 34.07 & 35.87 & 23.57 & 24.67 & 44.50 & 42.83 \\
WRC00 & $\%$ & 32.36 & 35.77 & 23.25 & 24.58 & 33.69 & 32.93 \\
\hline
\end{tabular}

nh: without hydrogel, h: with hydrogel, Trop: tropstrato, Bio: bioplant, Viv: vivatto. PH hydrogen potential, EC: electrical conductivity obtained in solution I:5 (v/v), WS: wet density, DD: dry density, CH: current humidity, TP: total porosity, AS: aeration space, RAW: readily available water, BW: buffering water, RW: remaining water, WRC 10, 50 AND 100: water retention capacity under suction of 10,50 and $100 \mathrm{~cm}$ of water column determining the volumetric base $(\mathrm{v} / \mathrm{v})$.

\section{Statistical treatments and procedures}

For the rooting evaluation (35 DAC), a completely randomized design was used in a 3x2 factorial scheme (three types of substrate $\mathrm{x}$ presence and absence of hydrogel) with four replicates of 10 mini-cuttings each. For the evaluation of the development and quality of seedlings, the same experimental arrangement was considered, but with five replicates of 10 seedlings each. After verification of the data homogeneity and normality, they were submitted to analysis of variance $(\alpha=0.05)$ and the means were compared by the Tukey test ( $\alpha=0.05)$ using Rbio software (BHERING, 2017).

The association between the traits related to rooting, seedling development and physical and chemical properties was quantified by the Pearson correlation. Correlations were expressed through the correlations network, where the proximity between nodes (traces) is proportional to the absolute value of the correlation between these nodes. The thickness of the edges was controlled by applying a cut-off value of 0.7 , which means that only $\left|\mathrm{r}_{\mathrm{ij}}\right| \geq 0.7$ have their edges highlighted. Positive correlations were highlighted in green, while negatives were represented in red. This analysis was performed on Rbio software (BHERING, 2017).

\section{RESULTS AND DISCUSSION}

Rooting quality of mini-cuttings at 35 DAC was influenced by treatments (Figure 2). The traits RM, C, MRL, RSL and NR showed significant interaction between substrate and hydrogel factors. The SM trait was influenced only by the substrate and the RSDM was not influenced by any factor.

Regardless of the use of the hydrogel, the Vivatto substrate provided higher values of SM, differing statistically only from Bioplant (Figure 2A). The incorporation of the hydrogel to the Vivatto and Tropstrato substrates did not influence the other rooting traits. On the Bioplant substrate, the hydrogel favored the rooting of the mini-cuttings, with a $32.5 \%$ increase in $\mathrm{RM}$, a reduction of $\mathrm{C}$ in $47.5 \%$ and, 
Neres et al. - Effect of the hydrogel incorporation on different substrates on the rooting and quality of clonal Eucalyptus seedlings
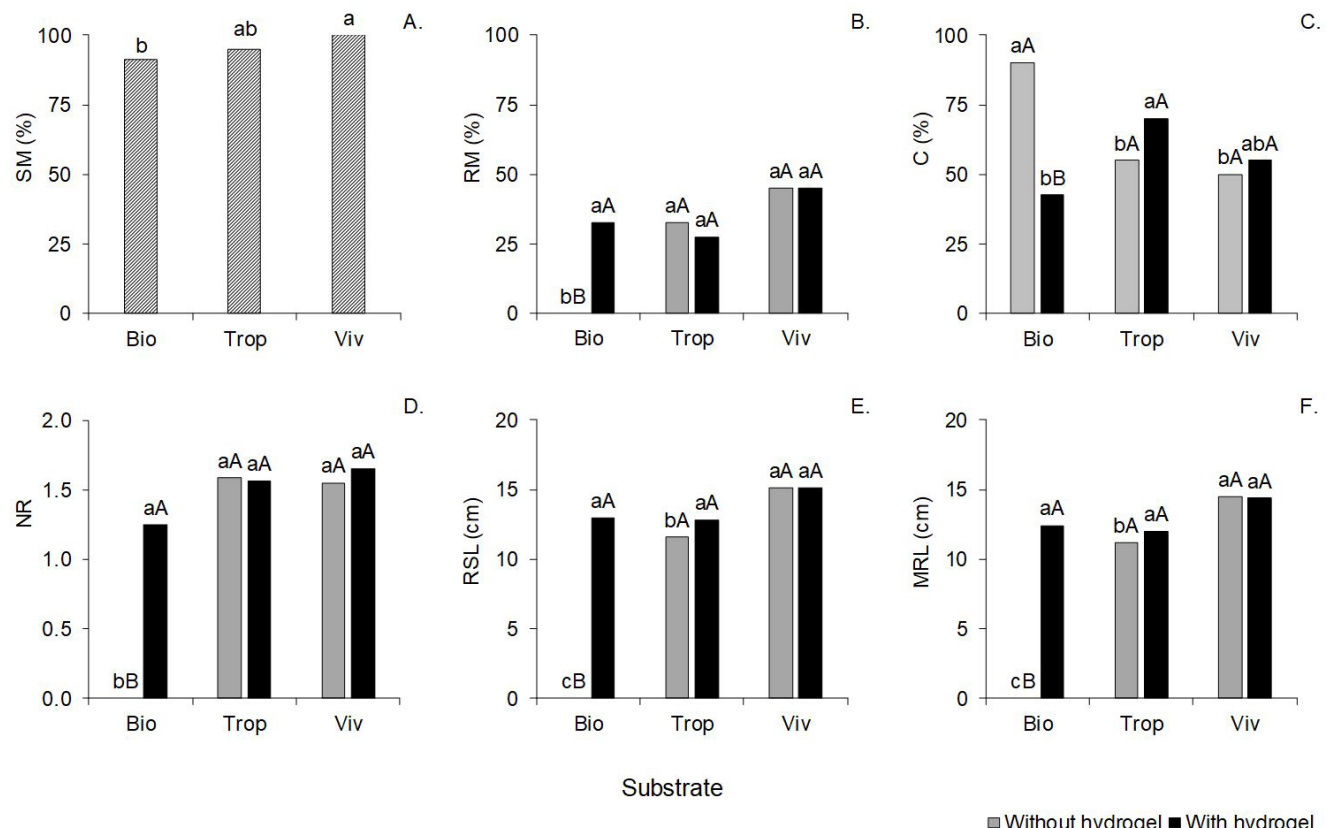

Figure 2. Percentages of survival (SM), rooting (RM) callus formation (C), number of roots (NR), root system length (RSL) and mean root length (MRL) of mini-cuttings of Eucalyptus camaldulensis $x$ Eucalyptus urophylla (clone VM01), produced on different substrates (Bio = Bioplant; Trop = Tropstrato; Viv = Vivatto), with 0 and $2 \mathrm{~g} \mathrm{~L}^{-1}$ of hydrogel. Lowercase letters differentiate the substrates with the same rate of hydrogel and uppercase letters differentiate the rates of the hydrogel in the same substrate, by the Tukey test $(a=0.05)$.

consequently, an increased NR, RSL and MRL values in relation to mini-cuttings produced without hydrogels (Figures 2B to 2F). Among the evaluated substrates, Bioplant was the one that presented worse performance, however, the use of the hydrogel promoted improvements in the rooting of mini-cuttings, making this substrate similar to the others.

The results obtained in the present work corroborate in part with those obtained by Azevedo et al. (2015), which evaluated the effect of hydrogel rates on rooting of mini-cutting of VM01 and AEC0144 clones (E. urophylla), (vermiculite, charcoal rice husk and coconut fiber (1: 1: 1)). These authors verified that, for the clone VM01, the traits SM, RM, NR, RSL, MRL and RSDM were influenced by different hydrogel rates incorporated into the substrate; for clone AEC0144, this effect was verified only for the SM, RM and MRL traits. The use of the hydrogel also provided an increase of $23 \%$ in MRL of the I144 clone (E. grandis $\mathrm{x}$ E. urophylla) (NICOLETTI et al., 2014). The reduction of C formation on cuttings with the use of the hydrogel was also observed by Hafle et al. (2008) when producing sweet passion fruit seedlings (Passiflora alata Cutis).

The results obtained demonstrate that the influence of the hydrogel on the rooting of mini-cuttings depends on the substrate properties. The substrate properties that most affected the rooting quality were AS and TP, which were correlated negatively with RM, NR, RSL and MRL (Figure 3). These traits were also negatively correlated with $\mathrm{C}$, which in turn presented a positive correlation with TP.

The TP, WRC10 and hence AS did not undergo significant changes with the incorporation of the hydrogel to the Vivatto and Tropstrato substrates (Table 1), which explains the absence of differences in the rooting quality between the treatments involving these substrates (Figure 2). In the Bioplant substrate, the highest rooting quality occurred with the presence of the hydrogel, as it reduced the AS and TP values of this substrate, making the TP similar to that observed for the other substrates. It is important to note that the higher rooting quality was obtained with values of TP below the appropriate range, from 75 to $85 \%$ (MAEDA et al., 2007).

The substrate properties EC and WRC50 showed a strong positive correlation between SM, and the RW with the NR (Figure 3). For the Bioplant substrate, EC values are lower than the range from 1.5 to $3.0 \mathrm{mS} \mathrm{cm}^{-1}$ (BUNT, 1988; RODRIGUES, 2002), and the WRC50 values are within the range from 20 to 30\% (VALERI, CORRADINI, 2000), considered suitable for producing forest seedlings. The highest SM was observed, however, on substrates with WRC50 values higher than the recommended range. These factors explain the lower SM values observed for this substrate (Figure 2). 


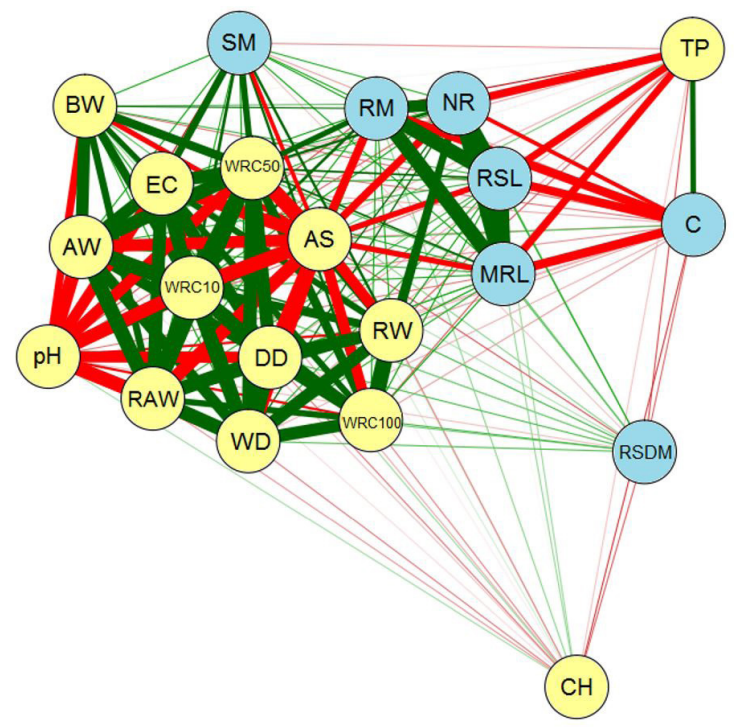

Figure 3. Correlations network between substrate properties and traits that express the rooting quality of mini-cuttings of Eucalyptus camaldulensis $x$ Eucalyptus urophylla (clone VM01), grown on different substrates, with 0 and $2 \mathrm{~g} \mathrm{~L}^{-1}$ hydrogel. The red and green lines represent negative and positive correlations, respectively. The width of the line is proportional to the strength of the correlation. Rooting traits: survival (SM), rooting (RM), callus formation (C), number of roots (NR), root system length (RSL), mean root length (MRL) and root system dry mass (RSDM). Substrate properties: electric conductivity (EC), hydrogen potential ( $\mathrm{pH}$ ), wet density (WD), dry density (DD), current humidity (CH), total porosity (TP), aeration space (AS), readily available water (RAW), buffering water $(B W)$, available water $(A W)$, remaining water (RW) and water retention capacity under suction of 10,50 and $100 \mathrm{~cm}$ of water column (WRC10, WRC50, WRC100).

Among the traits related to seedling development, only ND was influenced by the interaction between substrate and hydrogel factors (Figure 4A). The traits H, NL and HD were influenced only by the substrates (Figures 4B, 4C and 4D). The other traits did not present significant differences.

The incorporation of the hydrogel to the Bioplant substrate promoted an increase in ND values $(7.1 \%)$, while in the other substrates there was a reduction $(10.7 \%$ and $12.6 \%$ for Tropstrato and Vivatto, respectively). Without hydrogel, the Bioplant was inferior to the other substrates, being equal to they when incorporating the product. Regardless of the use of hydrogel, overall, Bioplant presented the worst performance for H, NL and HD traits.

The results found in the present study do not corroborate those found by Navroski et al. (2015), who observed a positive influence of hydrogel rates not only on NC, but also on H, SDM, RDM, TDM and DQI in seedlings of E. dunni by seed, at 90 days after sowing. Several works in the literature indicate the observed in this study, where the different substrates influence the development and quality of forest seedlings (SIMÕES; SILVA; SILVA, 2012)

For the development of the seedlings, the EA correlated negatively with the H, NL and HD traits. The other substrate properties, except UA, PT, $\mathrm{pH}$ and AT, showed a strong positive correlation between these traits (Figure 5). As with the rooting quality, the highest AS provided the worst performance in the seedling development, leading to infer that the genetic material evaluated needs a lower AS for a better rooting of the mini-cuttings and seedling development.

The substrates properties that presented the best rooting and seedling development were not necessarily within the ranges considered appropriate in the literature (BUNT, 1988; DELARMELINA et al., 2014; GONÇALVES; POGIANI, 1996; MAEDA et al., 2007; VALERI; CORRADINI, 2000; RODRIGUES, 2002). However, Silva, Simões and Silva (2012) point out that the values suggested as suitable in the literature should be used with greater criteria, since they do not apply to all species, types of containers, propagation forms, water and nutritional management and materials used in the composition of the substrates.

Most traits that express the seedling development are correlated with some rooting trait. The $\mathrm{H}$, NL and HD presented a positive correlation with RM, NR, MRL and RSL. On the other hand, the traits RDM, TDM and DQI were positively correlated with SRDM (Figure 6). These results allow inferring that the treatments with better rooting quality will provide the best development and final quality to the seedlings. 
Neres et al. - Effect of the hydrogel incorporation on different substrates on

the rooting and quality of clonal Eucalyptus seedlings
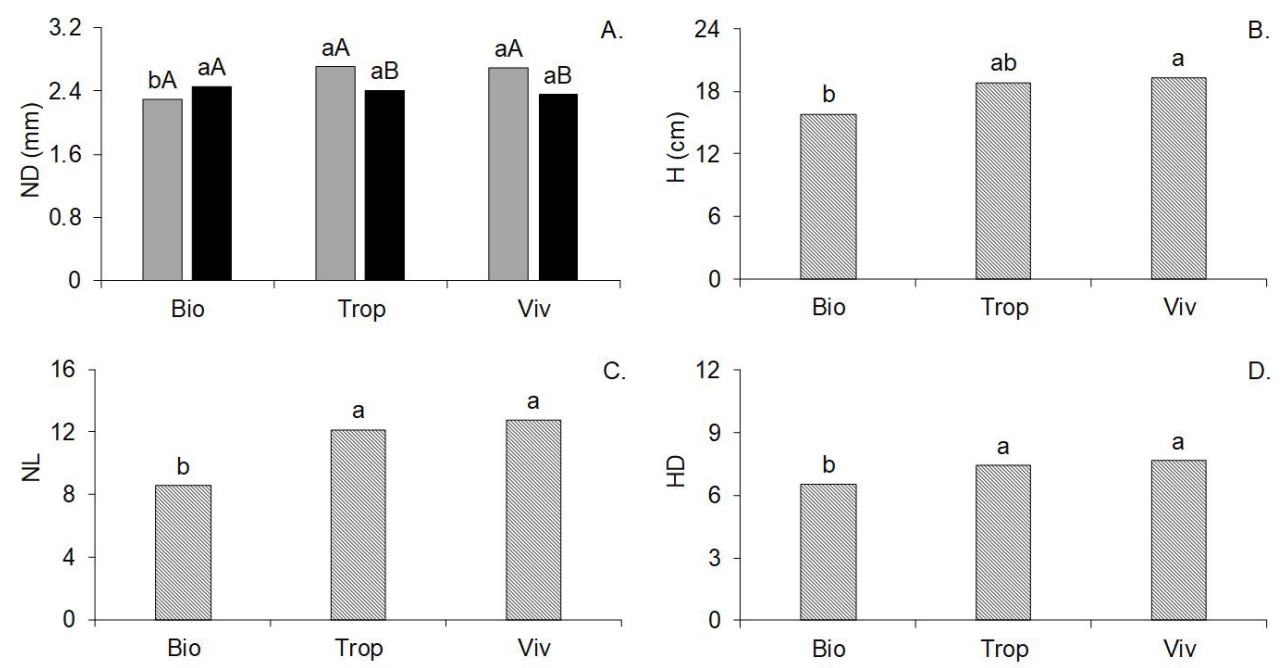

C.

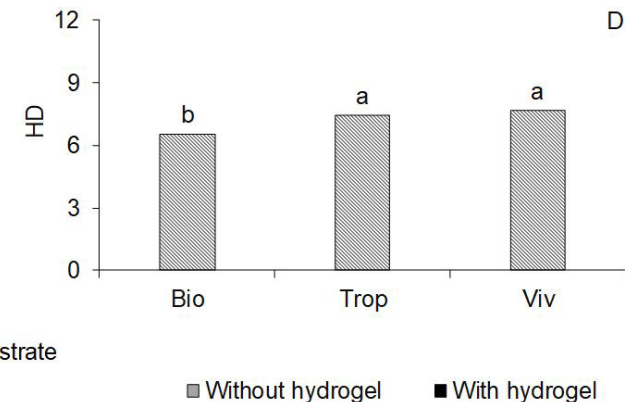

D.

Without hydrogel $\quad$ With hydrogel

Figure 4. Neck diameter (ND), shoot height $(H)$, number of leaves (NL) and height and diameter ratio (HD) of seedlings of Eucalyptus camaldulensis x Eucalyptus urophylla (clone VM01), produced on different substrates (Bio = Bioplant; Trop = Tropstrato; Viv = Vivatto), with 0 and $2 \mathrm{~g} \mathrm{~L}^{-1}$ of hydrogel. Lowercase letters differentiate the substrates with the same rate of hydrogel and uppercase letters differentiate the rates of the hydrogel in the same substrate, by the Tukey test $(a=0.05)$.

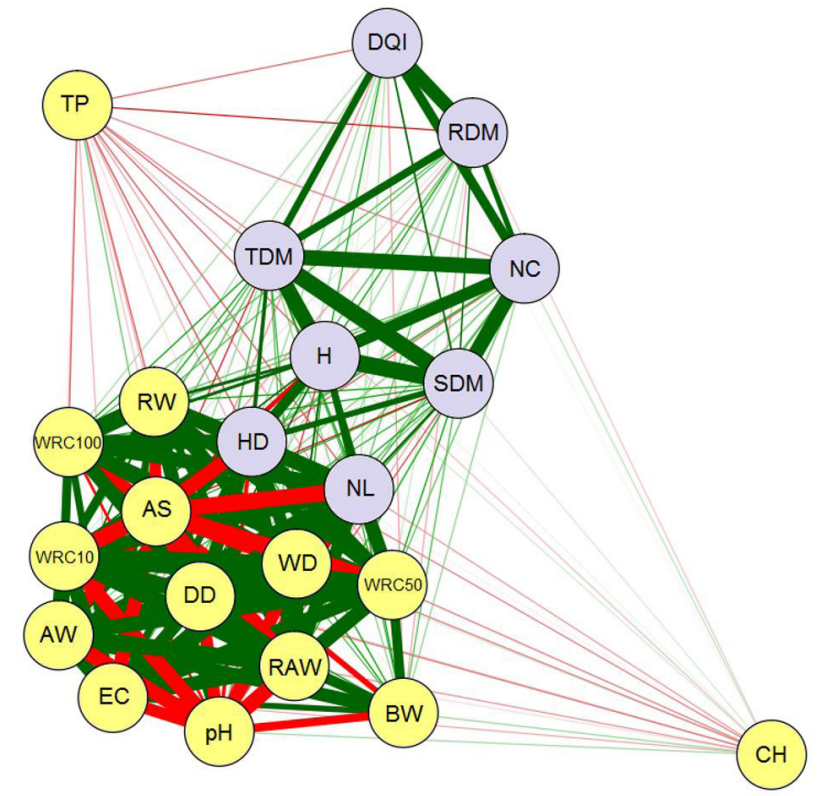

Figure 5. Correlations network between substrate properties and traits that express the seedling development of Eucalyptus camaldulensis x Eucalyptus urophylla (clone VM01), grown on different substrates, with 0 and $2 \mathrm{~g} \mathrm{~L}^{-1}$ hydrogel. The red and green lines represent negative and positive correlations, respectively. The width of the line is proportional to the strength of the correlation. Development traits: neck diameter (ND); shoot height (H); number of leaves (NL); shoot dry mass (SDM), root dry mass (RDM) and total dry mass (TDM); height and diameter ratio (HD) and Dickson quality index (DQI). Substrate properties: electric conductivity $(\mathrm{EC})$, hydrogen potential $(\mathrm{pH})$, wet density $(\mathrm{WD})$, dry density $(\mathrm{DD})$, current humidity $(\mathrm{CH})$, total porosity (TP), aeration space (AS), readily available water (RAW), buffering water (BW), available water (AW), remaining water (RW) and water retention capacity under suction of 10,50 and $100 \mathrm{~cm}$ of water column (WRC10, WRC50, WRC100).

Although the trait $\mathrm{C}$ is negatively correlated with the other rooting traits, it presents a weak negative correlation with traits that express the seedling development (Figure 6). This is an indication that root formation occurred in these seedlings even after $35 \mathrm{DAC}$, thus allowing the seedling to complete its development. Callus and roots formation are independent processes in most plants (GOULART et al., 2014), but in some of them, callus formation can be a precursor to the formation of adventitious roots (GOULART et al., 2014; OLIVEIRA et al., 2012). 


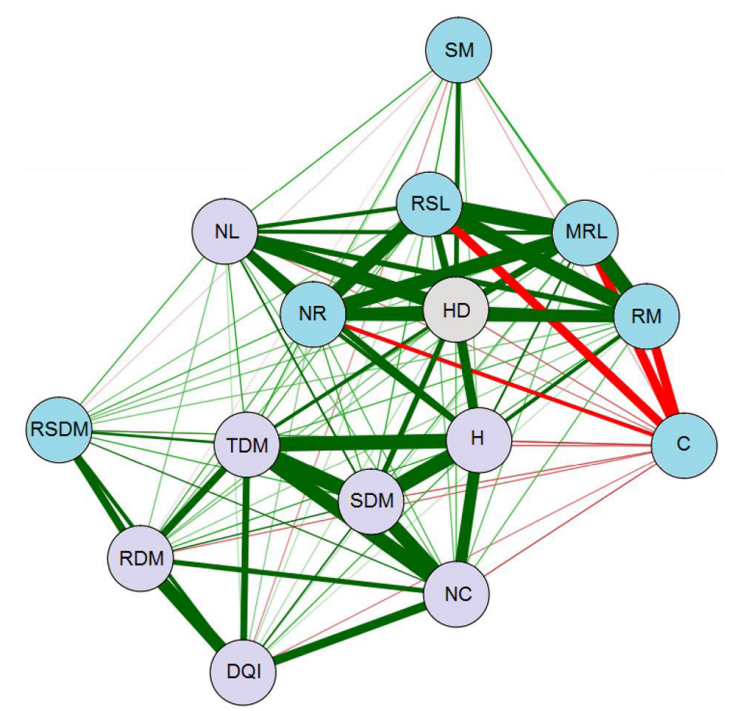

Figure 6. Correlations network between traits that express the rooting quality of mini-cuttings and traits related to seedling development of Eucalyptus camaldulensis x Eucalyptus urophylla (clone VM01), grown on different substrates, with 0 and $2 \mathrm{~g} \mathrm{~L}^{-1}$ hydrogel. The red and green lines represent negative and positive correlations, respectively. The width of the line is proportional to the strength of the correlation. Development traits: neck diameter (ND); shoot height $(\mathrm{H})$; number of leaves (NL); shoot dry mass (SDM), root dry mass (RDM) and total dry mass (TDM); height and diameter ratio (HD) and Dickson quality index (DQI). Rooting traits: survival (SM), rooting (RM) callus formation (C), number of roots (NR), root system length (RSL), mean root length (MRL) and root system dry mass (RSDM).

In species with difficult rooting, the substrate can influence both the rooting percentage and the quality of the formed root system (XAVIER; WENDLING; SILVA, 2009). The results here obtained demonstrate that the hydrogel incorporation into the substrate of seedlings production can be a promising alternative to improve the rooting quality and seedling development. However, it is important to highlight that the efficiency of this product depends, among other factors, on the physical and chemical properties of the substrates used in seedling production.

Due to the hydrogel does not effectively influence the physical and chemical properties of two substrates analyzed, studies evaluating the response of the rooting and seedling development in mini-cuttings grown on different substrates in combination with different hydrogel rates are necessary.

\section{CONCLUSIONS}

Rooting quality and seedling development of mini-cuttings are influenced by the different substrates used.

The hydrogel efficiency for improving the rooting quality and seedling development in minicuttings depends on the physical and chemical properties of the substrates, as electric conductivity, total porosity, aeration space and water retention capacity.

The best rooting quality provides the best development and final quality of seedlings.

\section{ACKNOWLEDGEMENTS}

The authors acknowledge the support of the Universidade Federal de Mato Grosso do Sul. This study was financed in part by the Coordenação de Aperfeiçoamento de Pessoal de Nível Superior Brasil (CAPES) - Finance Code 001.

\section{REFERENCES}

ALFENAS, A. C.; ZAUZA, E. A. V.; MAFIA, R. G.; ASSIS, T.F. Clonagem e doenças do eucalipto. Viçosa: Editora UFV, 2004. $442 \mathrm{p}$. 
Neres et al. - Effect of the hydrogel incorporation on different substrates on

the rooting and quality of clonal Eucalyptus seedlings

AZEVEDO, G. T. O. S.; SOUZA, A. M.; AZEVEDO, G. B.; CERQUEIRA, P. H. A. Enraizamento de miniestacas de eucalipto com diferentes doses de polímero hidroretentor incorporado ao substrato. Scientia Forestalis, Piracicaba, v. 43, n. 108, p.773-780, 2015.

BENIN, C. C.; PERES, F. S. B.; GARCIA, F. A. DE O. Enraizamento de miniestacas apicais, intermediárias e basais em clones de Eucalyptus benthamii. Revista Floresta, Curitiba, v. 43, n. 3, p.421-428, 2013.

BERNARDI, M. R.; SPEROTTO, JUNIOR, M.; DANIEL, O.; VITORINO, A. C. T. Crescimento de mudas de Corymbia citriodora em função do uso de hidrogel e adubação. Revista Cerne, Lavras, v. 18, n. 1, p. 67-74, 2012

BHERING, L. L. Rbio: A Tool for Biometric and Statistical Analysis Using the R Platform. Crop Breeding and Applied Biotechnology, v. 17, n.2, p.187-190, 2017.

BÖHM, W. Methods of studying root systems. Berlin: Springer-Verlag, 1979. 188 p.

BRASIL. MAPA - MINISTÉRIO DA AGRICULTURA, PECUÁRIAE ABASTECIMENTO. Métodos analíticos oficiais para análise de substratos para plantas e condicionadores de solo. Instrução Normativa NDA N 17.2007. Disponível em: < http://www.agricultura.gov.br/assuntos/insumos-agropecuarios/insumos-agricolas/fertilizantes/ legislacao/in-17-de-21-05-2007-aprova-metodo-substrato.pdf >. Acesso em: 10 nov. 2018.

BRONDANI, G. E.; BASCARIN, F. J. B.; BERGONCI, T.; GONÇALVEZ, A. N.; ALMEIDA, M. A. Miniestaquia de Eucalyptus benthamii: efeito do genótipo, AIB, zinco, boro e coletas de brotações. Cerne, Lavras, v. 20, n. 1, p. 147-156, 2014.

BUNT, A.C. Media and mixes for container grown plants: a manual on the preparation and use of growing media for pot plants. London: Unwin Hyman, 1988. 309 p.

DANNER, M. A.; CITADIN, I.; FERNANDES JÚNIOR, A. A.; ASSMAN, A. P.; MAZARO, S. M.; SASSO, A. A.Z. Formação de mudas de jabuticabeira (Plinia sp.) em diferentes substratos e tamanhos de recipientes. Revista Brasileira de Fruticultura, Jaboticabal v. 29, n. 1, p.179-182, 2007.

DELARMELINA, W. M.; CALDEIRA, M. V. W.; FARIA, J. C. T.; GONÇALVES, E. O.; ROCHA R. L. F. Diferentes substratos para a produção de mudas de Sesbania virgata. Floresta e Ambiente, Seropédica, v. 21, n. 2, p.224233, 2014.

FERMINO, M. H.; KAMPF, A. N. Densidade de substratos dependendo dos métodos de análise e níveis de umidade. Revista de Horticultura Brasileira, Vitória da Conquista, v. 30, n. 1, p.75-79, 2012.

FERRARI, M. P.; GROSSI, F.; WENDLING, I. Propagação vegetativa de espécies florestais. Colombo: Embrapa Florestas, 2004. 22 p.

GONÇALVES, J. L. M.; POGGIANI, F. Substratos para produção de mudas florestais. In: CONGRESSO LATINO AMERICANO DE CIÊNCIA DO SOLO, 13., 1996, Águas de Lindóia. Resumos... Piracicaba: Sociedade Latino Americana de Ciência do Solo, 1996. CD-ROM.

GOULART, P.B.; XAVIER, A.; IAREMA, L.; OTONI, W.C. Morfoanatomia da rizogênese adventícia em miniestacas de Eucalyptus grandis $\times$ Eucalyptus urophylla. Ciência Florestal, Santa Maria, v. 24, n. 3, p.521-532, 2014.

HAFLE, O. M.; CRUZ, M. C. M.; RAMOS, J. D.; RAMOS, P. S.; SANTOS, V. A. Produção de mudas de maracujazeirodoce através da estaquia utilizando polímero hidrorretentor. Revista Brasileira de Ciências Agrárias, Pernambuco, v. 3, n. 3, p.232-236, 2008.

HARTMANN, H. T.; KESTER, D.; DAVIS, F; GENEVE, R. Plant propagation: principles and practices. 8.ed. Boston: Prentice-Hall, 2011. 915 p.

LIU, F.; MA, H.; XING, S.; DU, Z.; MA, B.; JING, D. Effects of super-absorbent polymer on dry matter accumulation and nutrient uptake of Pinus pinaster container seedlings. Journal of Forest Research, Otawa, v. 18, n. 3, p. 220-227, 2013.

MAEDA, S.; DEDECEK, R. A.; AGOSTINI, R. B.; ANDRADE, G. C.; SILVA, H. D. Caracterização de substratos para produção de mudas de espécies florestais elaborados a partir de resíduos orgânicos. Pesquisa Florestal Brasileira, Colombo, v. 54, p. 97-104, 2007.

MALDONADO-BENITEZ, K. R. M.; ALDRADE, A.; LÓPEZ-UPTON, J.; VAQUERA-HUERTA, H.; CENTINA-ALCAL, M. Produción de Pinus greggii Engelm. en mezclas de sustrato con hidrogel e riego, en vivero. Agrociencia, Cidade do México, v. 45, n. 3, p.389-398, 2011.

MELO, L. A.; XAVIER, A.; PAIVA, H. N.; BORGES, S. R. Otimização do tempo necessário para o enraizamento de miniestacas de clones de híbridos de Eucalyptus grandis. Revista Árvore, Viçosa, v. 35, n. 4, p.759-767, 2011. 
MEWS, C. L. et al. Efeito do Hidrogel e Ureia na Produção de Mudas de Handroanthus ochraceus (Cham.) Mattos. Floresta e Ambiente, Seropédica, v. 22, n. 1, p.107-116, 2015.

NAVROSKI, M. C.; ARAÚJO, M. M; PEREIRA, M. O; FIOR, C. S. Influência do polímero hidroretentor nas características do substrato comercial paraprodução de mudas florestais. Interciencia, Venezuela, v. 41, n. 5, p.357-361, 2016a.

NAVROSKI, M. C.; ARAÚJO, M. M.; REINIGER, L. R. S.; FIOR, C. S; SCHAFER, G.; PEREIRA, M. O. Initial growth of seedlings of Eucalyptus dunnii maiden as influenced by the addition of natural polymer and farming substrates. Revista Árvore, Viçosa, v. 40, n. 4, p. 627-637, 2016b.

NAVROSKI, M. C.; ARAÚJO, M. M; CUNHA, F. S.; BERGHETHI, A. L. P.; PEREIRA, M. O. Redução da adubação e melhoria das características do substrato com o uso do hidrogel na produção de mudas de Eucalyptus dunnii Maiden. Ciência Florestal, Santa Maria, v. 26, n. 4, p. 1155-1165, 2016c.

NAVROSKI, M. C.; ARAÚJO, M. M.; REINIGER, L. R. S.; MUNIZ, M. F. B.; PEREIRA, M. O. Influência do hidrogel no crescimento e no teor de nutrientes das mudas de Eucalyptus dunnii. Revista Floresta, Curitiba, v. 45, n. 2, p.315-328, 2015.

NICOLETTI, M. F; NAVROSKI, M. C.; ANDRIOLLO, K.; PEREIRA, M. O.; FRIGOTTO, T. Efeito do hidrogel no enraizamento e crescimento inicial de miniestaca do híbrido Eucalyptus urograndis. Cultivando o Saber, Cascavel, v. 7, n. 4, p. 353 - 361, 2014.

OLIVEIRA, Y.; ALCANTARA, G. B.; GUEDES, I.; PINTO, F.; QUOIRIN, M.; BIASI, L. A. Substratos, concentrações de ácido indolbutírico e tipos de miniestacas no enraizamento de melaleuca (Melaleuca alternifolia Cheel). Revista Brasileira de Plantas Medicinais, Botucatu, v. 14, n. 4, p. 611-616, 2012.

PIMENTEL, N.; BISOGNIN, D. A.; LENCINA, K. H.; MELLO, U. S. Shoot segment and substrate composition in rooting of juvenile ipe-roxo mini-cuttings. Ciencia Rural, Santa Maria, v. 46, n. 6, p. 996-1002, 2016.

RODRIGUES, L. R. F. Técnicas de cultivo hidropônico e de controle ambiental no manejo de pragas, doenças e nutrição vegetal em ambiente protegido. Jaboticabal: FUNEP, 2002. 762 p.

SANTANA, R. C.; FERNANDES, S. J. O.; TITON, M.; XAVIER, A.; SOUZA, P. F.; BARROS FILHOS, N. F. Effect of minicutting length and leaf area reduction on growth and nutritional status of Eucalypt propagules. ISRN Forestry, v. 2013, p.1-6, 2013.

SANTOS, F. R.; RAMALHO, L. S.; MARQUES, T. A.; SENA-SOUZA, J. P.; REATTO, A.; MARTINS, E. S.; COUTO JÚNIOR, A. F; NARDOTTO, A. G. Teor de carbono orgânico no solo e aspectos biofísicos da cobertura vegetal da bacia do Córrego Sarandi, Planaltina. Planaltina: Embrapa Cerrados, 2014. 28 p. (Boletim de Pesquisa e Desenvolvimento, 319)

SILVA, R. B. G; SIMÕES, D.; SILVA, M. Qualidade de mudas clonais de Eucalyptus urophylla x E. grandis em função do substrato. Revista Brasileira Engenharia Agrícola e Ambiental, Campina Grande, v. 16, n. 3, p. 297-302, 2012.

SIMÕES, D.; SILVA, R. B. G.; SILVA, M. R. Composição do susbstrato sobre o desenvolvimento, qualidade e custo de produção de mudas de Eucalyptus grandis Hill x Eucalyptus urophylla S. T. Blake. Ciência Florestal, Santa Maria, v. 22, n. 1, p.91-100, 2012.

SOUSA, G. T. O.; AZEVEDO, G. B.; SOUSA, J. R. L.; MEWS, C. L.; SOUZA, A. M. Incorporação de polímero hidroretentor no substrato de produção de mudas de Anadenanthera peregrina (L.) Speg. Enciclopédia Biosfera, Goiânia, v. 9, n. 16, p. 1270-1278, 2013.

TITON, M.; XAVIER, A.; REIS, G. G.; OTONI, W. C. Eficiência das minicepas e microcepas na produção de propágulos de clones de Eucalyptus grandis. Revista Árvore, Viçosa, v. 27, n. 5, p. 619-625, 2003.

VALERI, S. V.; CORRADINI, L. Fertilização em viveiros para produção de mudas de Eucalyptus e Pinus. In: GONÇALVEZ, J. L. M, BENEDETTI, V. (Eds). Nutrição e Fertilização Florestal. Piracicaba: IPEF, 2000. p. $167-190$.

VICENTE, M. R.; MENDES, A. A.; SILVA, N. F.; OLIVEIRA, F. R.; MOTTA JÚNIOR, M. G.; LIMA, V. O. B. Uso de gel hidroretentor associado à irrigação no plantio do eucalipto. Revista Brasileira de Agricultura Irrigada, Fortaleza, v. 9, n. 5, p.344-349, 2015.

WENDlinG, I.; DUTRA, L. F. Produção de mudas de eucalipto. Colombo: Embrapa Florestas; 2010.

XAVIER, A.; WENDLING, I.; SILVA, R. L. Silvicultura clonal princípios e técnicas. Viçosa: Ed. UFV, 2009. 272 p.

Received: $11 / 22 / 2017$

Accepted: 10/05/2018

Sci. For., Piracicaba, v. 47, n. 122, p. 336-345, jun. 2019

DOI: doi.org/10.18671/scifor.v47n122.16 